\title{
Scaling Up Agroforestry Farming Systems: Lessons from the Malawi Agroforestry Extension Project \\ Http://dx.doi.org/10.4314/jae.v20i1.13
}

\author{
Kakhobwe, C.M. \\ Lilongwe University of Agriculture and Natural Resources, Bunda Campus, P.O Box 219, \\ Lilongwe, Malawi. chisomokb@gmail.com; +265888168803
}

Kamoto, J. F.

Lilongwe University of Agriculture and Natural Resources, Bunda Campus, P.O Box 219, Lilongwe, Malawi judithkamoto@gmail.com; +265 992676901

\author{
Njoloma, J. P \\ Lilongwe University of Agriculture and Natural Resources, Bunda Campus, P.O Box 219, \\ Lilongwe, Malawi injoloma@yahoo.com +265 888727857
}

\section{Ozor, Nicholas}

African Technology Policy Studies Network (ATPS), $3^{\text {rd }}$ Floor, Chancery Building, Valley Road, P.O. Box 100-00100, Nairobi, Kenya. nozor@atpsnet.org; +254 713161928

\begin{abstract}
The study examined the factors affecting agroforestry technology upscaling and identified gaps in scaling up approaches of agroforestry technologies. One hundred and sixty-four farmers in Malawi Agroforestry Extension (MAFE) project districts of Mzimba, Ntcheu and Mangochi were interviewed. Logistic model was used in analysing data from the study. Results show that farmers' extension access, perceived usefulness of agroforestry technology, main source of income, educational level of household head, and number of field plots were the main factors affecting the scaling up of the agroforestry technologies in the area. Among others, the study recommended that farmers and extension workers should be actively and jointly engaged in the design of agroforestry projects for effective upscaling and that agroforestry extension services should be promoted for farmers to perceive the usefulness of the technologies to enhance scaling up of the technology.
\end{abstract}

Key words: Malawi Agroforestry, Soil fertility, Scaling up of agroforestry.

\section{Introduction}

Malawi is an agro-based country, which depends mainly on maize as staple food. However, maize production faces many challenges especially declining soil fertility (Malawi Government, 2012). In trying to solve the problem, the Malawi Agroforestry Extension Project (MAFE) was implemented between 1992 and 2002. The project had numerous achievements during the implementation period but there is little continuation and scale up of the agroforestry activities in the project sites after the project phased out in 2002. Scaling up agroforestry technology is important because 
Creative commons User License: CC BY-NC-ND

Abstracted by: EBSCOhost, Electronic Journals Service (EJS),

Google Scholar, Directory of Open Access Journals (DOAJ),

Journal Seek, Scientific Commons,

Food and Agricultural Organization (FAO), andCABI
Journal of Agricultural Extension

Vol. 20 (1) June, 2016

ISSN(e): 24086851; ISSN(Print); 1119944X

http://journal.aesonnigeria.org

http://www.ajol.info/index.php/iae

Email: editorinchief@aesonnigeria.org

soils in Malawi lose nutrients at annual rates of not less than $40 \mathrm{~kg}$ of nitrogen $(\mathrm{N})$, $6.6 \mathrm{~kg}$ phosphorus (P) and $33.2 \mathrm{~kg}$ potassium (K) per hectare (Makumba, 2003). In order to sustain crop production in Malawi, farmers mainly rely on inorganic fertilizers. However, its sustainability is becoming even more difficult to achieve because the inorganic fertilizers are becoming unaffordable to most smallholder farmers due to the rise in prices (Kwesiga et al., 2003). This high cost of fertilizers has resulted in low application rates of less than $10 \mathrm{~kg} /$ hectare among smallholder farmers (Policy Analysis and Sustainable Agricultural Development in Central, Eastern Europe and Southern Africa (PASAD), 2005). For example, average prices of a $50 \mathrm{~kg}$ bag of fertilizers like 23:21:0 + 4S, UREA and Calcium Ammonium Nitrate (CAN) increased nearly fifteen times from an average of MK100.00 in 1994/95 to over MK1500 in 2004. In 2015, the average market price for UREA was MK 17,450. CAN was selling at MK17, 550 while 23:21:0 + 4S was selling at MK19, 600 per $50 \mathrm{~kg}$ bag. Taking into account the increasing costs of inorganic fertilizer, low-cost soil fertility improvements that enhance crop productivity like agroforestry need to be promoted.

The Malawi agricultural policy highlights the need for sustainable management and utilization of natural resources (Malawi Government, 2012). The National Land Resources Management Strategy calls for efficient, diversified and sustainable use of land based resources. Agroforestry is one of the potential interventions emphasized in the strategy (Malawi Government, 2000). Some of the agroforestry technologies being commonly practiced in Malawi include mixed intercropping, annual under sowing, dispersed systematic intercropping homestead, boundary and Woodlots (Malawi Government, 2012). In relay cropping, maize is planted at the onset of rain, but planting of the trees is delayed for about two weeks after the maize has been planted. Trees continue growing on the piece of land after the crop has been harvested, forming a short-term fallow during the dry season. Before the next rainy season, trees are cut and all the leafy biomass is incorporated into the soil and the poles are harvested for either light construction or fuel wood (Makumba, 2003).

Despite the emphasis of agroforestry in key national agricultural working documents like the agricultural policy, the National Land Resources Management Strategy, and Guide to Agricultural Production and Natural Resources Management Handbook, the agroforestry potential to improve maize production, scaling up remains the challenge in the country. The study was also commissioned on the background that the Malawi government through the department of Land Resources Conservation is currently developing a National Agroforestry Policy intended to scale up uptake of the technology by the small holders.

\footnotetext{
${ }^{1} 1 \mathrm{USD}=\mathrm{MK} 710$
} 
Creative commons User License: CC BY-NC-ND

Abstracted by: EBSCOhost, Electronic Journals Service (EJS),

Google Scholar, Directory of Open Access Journals (DOAJ),

Journal Seek, Scientific Commons,

Food and Agricultural Organization (FAO), andCABI
Journal of Agricultural Extension

Vol. 20 (1) June, 2016

ISSN(e): 24086851; ISSN(Print); 1119944X

http://journal.aesonnigeria.org

http://www.ajol.info/index.php/jae

Email: editorinchief@aesonnigeria.org

\section{Purpose of the Study}

The overall purpose of the study was to draw lessons for upscaling of agroforestry by identifying the factors that have led to no, or low continuation of MAFE project activities after project phasing out in 2002.

Specifically, the study aimed to:

1. determine factors affecting agroforestry technology scaling up;

2. identify gaps in implementation and scaling up of agroforestry technologies; and

3. recommend best-bet practices for scaling up agroforestry technologies.

\section{Methodology}

The study was conducted in Mzimba, Ntcheu and Mangochi districts in Malawi. In Mzimba district, the study was done inKazombe Extension Planning Area (EPA); in Ntcheu district the study was done in Njolomole EPA, while in Mangochi district the study was done in Nthilamanja EPA. These EPAs were purposively selected for the study as they were part of the MAFE project sites and to have representation of all the three agro-ecological zones of Malawi (Low, Medium and high altitude). The study was undertaken in the 2011/12 cropping season.

Study population consisted of farmers who participated in the implementation of MAFE project activities (targeted) and those who did not participate (non-targeted) in the three EPAs. The entire populations of 164 farmers were interviewed in the study (83 targeted and 81 non-targeted). Simple random sampling was used to identify the farmers that participated in the study.

A Logistic regression model was used to examine factors responsible for scaling up of agroforestry technologies. The dependent variable was whether the farmer is still practicing agroforestry after MAFE project phased out in 2002. The model was chosen because the dependent variable had two possible outcomes 'Yes' and 'No' where 'Yes' $=1-$ farmer still practicing agroforestry after the project and 'No' $=0-$ farmer not practicing agroforestry. As theoretically determined in literature, Logistic model was more appropriate for this analysis because it could identify the factors affecting scale up of agroforestry technologies (Agresti, 2007 and Gujarat, 2004). When the dependent variable is binary and can only take two values, use of ordinary multiple regression techniques and discriminant analysis are not suitable because a number of essential assumptions of such models are not satisfied and the predicted values cannot be interpreted as probabilities (Jabbar, Beyene, Saleeem, and Gebreselassie, 1998). Multinomial model would have been more applicable if there were three responses for the dependent variable: Linear regression was not used because it would violate the linearity assumption (Gujarati, 2004).

Logistic regression model also requires far fewer assumptions but directly estimates the probability of an event occurring or not occurring. In logistic regression, Forward Stepwise maximum likelihood method is used to estimate parameters (Jabbar et al., 1998). Statistical Package for Social Scientists (SPSS) was used for the data 
Creative commons User License: CC BY-NC-ND

Abstracted by: EBSCOhost, Electronic Journals Service (EJS),

Google Scholar, Directory of Open Access Journals (DOAJ),

Journal Seek, Scientific Commons,

Food and Agricultural Organization (FAO), andCABI
Journal of Agricultural Extension

Vol. 20 (1) June, 2016

ISSN(e): 24086851; ISSN(Print); 1119944X

http://journal.aesonnigeria.org

http://www.ajol.info/index.php/iae

Email: editorinchief@aesonnigeria.org

analysis. To determine the influence of perceptions (Perceived Ease of Use-PEOU and Perceived Usefulness-PU), age, education, income source, extension access, field day attendance, household land size, household size and household labour availability on agroforestry scale up, a regression using the binary Logistic model, using forward stepwise method was conducted (Field, 2000 and Gujarat, 2004). The dependent variable $(\mathrm{Y})$ was a natural log of the probability of scaling up agroforestry technology or not.

The Logistic Model

Logistic $[\varnothing(x)]=\log [\varnothing(x) / 1-\varnothing(x)]=\alpha+\beta_{1} x_{1}+\beta_{2} x_{2}+\ldots .+\beta_{i} x_{i}+\ldots e$

Where:

$\alpha=$ the constant of the equation

$h \beta=$ the coefficient of the predictor variables.

$\mathrm{E}=$ error term

This can be simply expressed as follows

$Y_{1}=\ln (P / 1-P)=f\left(X_{1}, X_{2}, X_{3}, X_{4}, X_{5}, X_{6}, X_{7}, X_{8}, X_{9}, X_{10}, X_{11}\right)+e$ Equation (2)

Where:

$Y_{1}=$ whether the farmer adopted agroforestry technology after the project phased out or not

$X_{1}=$ sex of household head (male or female)

$X_{2}=$ marital status of the household head (single, married, widowed, divorced)

$X_{3}=$ age of the household head (number of years)

$X_{4}=$ education level of the household head (primary, secondary, tertiary, adult literacy)

$X_{5}=$ household main income source (selling own farm produce, small scale trading-owning a grocery, carpentry, buying and selling farm produce)

$X_{6}=$ extension access (visits to extension worker, visits by extension worker for advice,

attendance of extension training and meetings)

$X_{7}=$ field day attendance (number of field days on soil fertility enhancing technologies

attended)

$X_{8}=$ household land size (number of hectares)

$X_{9}=$ household size (total number of usual residents in the household)

$X_{10}=$ household labour availability (conversion rates by availability of household member, sex and age)

$X_{11}=$ Farmers Perceived Technology Characteristics (perceived usefulness (PU) and perceived ease of use (PEOU) using Technology Acceptance Model (TAM)

$\mathrm{e}=$ the error term

\section{Results and Discussion}

\section{Factors affecting scaling up of Agroforestry}

The results showed that household main income source, extension access, household head education level, household number of fields, PU, PEOU and attendance to field days with emphasis on soil fertility enhancement technologies 
Creative commons User License: CC BY-NC-ND

Abstracted by: EBSCOhost, Electronic Journals Service (EJS),

Google Scholar, Directory of Open Access Journals (DOAJ),

Journal Seek, Scientific Commons,

Food and Agricultural Organization (FAO), andCABI
Journal of Agricultural Extension

Vol. 20 (1) June, 2016

ISSN(e): 24086851; ISSN(Print); 1119944X

http://journal.aesonnigeria.org

http://www.ajol.info/index.php/iae

Email: editorinchief@aesonnigeria.org

were significant at $5 \%$ (Table 1). The household's main source of income is the important factor to consider in scaling up agroforestry technology. According to Chamdimba (2003), agroforestry increases crop yield and consequently household income. This means that farmers whose main source of income is crop sales are more likely to invest in technologies that will increase their yield like agroforestry technology than those with other main sources of income. Hence working with those farmers is very crucial in scaling up agroforestry technologies.

This finding emphasizes the fact that the Department of Land Resources Conservation in the Ministry of Agriculture and Food Security in Malawi need to adopt a three-way strategy. Firstly, there is need to focus attention on low income and resource constrained farmers, especially poor resource farmers who cannot afford inorganic fertilizers. Secondly, there is need to promote co-management of soil fertility problem among the better-off households to obtain the best results from investment in mineral fertilizers because their households have access to inorganic fertilizer. Utilization of these organic technologies helps improve the organic matter content of the soil. Evidence shows that returns from use of inorganic fertilizers are maximized when organic and inorganic fertilizers are combined Thangata, P.H., Alavalapati, J.R.R. (2003). Lastly, farmers whose main source of income is crop sales should incorporate agroforestry trees, which can include homestead and field boundary planting in tobacco growing areas. This is because farmers whose main source of income is crop sale are likely to invest in technologies that will increase their yield output like agroforestry technologies. According to Kamoto et al., (2013) farmers are investing in tree management where benefits of investment are known.

Table 1: Factors for scaling up of agroforestry

\begin{tabular}{lll}
\hline Characteristic & Coefficient & Std. Error \\
\hline Sex & -0.106 & 0.446 \\
Household size & 0.006 & 0.033 \\
Age of household head & -0.00 & 0.004 \\
Main income source & $0.109^{*}$ & 0.060 \\
Education level & $0.290^{*}$ & 0.166 \\
Extension access & $0.585^{*}$ & 0.233 \\
Household land size (ha) & 0.095 & 0.400 \\
Field days & $0.723^{*}$ & 0.302 \\
No. of fields & $-1.196^{*}$ & 0.564 \\
Marital status & 0.763 & 0.544 \\
Labour & 0.245 & 0.343 \\
Perceived Usefulness & $0.145^{*}$ & 0.086 \\
\hline
\end{tabular}

${ }^{*}<0.05$

Extension access and field days, which are the commonest ways of information dissemination channel, were also significant. This means that extension access by farmers, and participation in soil enhancement technologies, field days increases agroforestry technology scale up. It is inevitable that extension does create the necessary awareness to farmers and help to motivate more farmers to invest in 
Creative commons User License: CC BY-NC-ND

Abstracted by: EBSCOhost, Electronic Journals Service (EJS),

Google Scholar, Directory of Open Access Journals (DOAJ),

Journal Seek, Scientific Commons,

Food and Agricultural Organization (FAO), andCABI
Journal of Agricultural Extension

Vol. 20 (1) June, 2016

ISSN(e): 24086851; ISSN(Print); 1119944X

http://journal.aesonnigeria.org

http://www.ajol.info/index.php/iae

Email: editorinchief@aesonnigeria.org

agroforestry as an organic soil fertility technology. Educational level was also significant. Farmers' educational level is also important because literate farmers understand and practice modern farming technologies more than the illiterate ones and they can also be used as lead farmers. Matata (2009) reported that fellow farmers were $76 \%$ more effective in dissemination of improved fallow agroforestry technology information than government extension workers. This can be explained by the fact that farmers are able to understand each other better and appreciate what others are doing than just being told by government extension workers. The education level of the farmer is also expected to have a positive impact on the decision making process on agroforestry technologies scaling up. In a similar study by Ozor et al (2013), they found that farmers who were more educated were more willing to pay for improved agricultural technologies and extension services. It is expected that heads of households with six or more years of education will be able to understand the benefits of agroforestry. This is because at higher levels of education, the school curriculum may have covered general principles of agricultural and agroforestry practices. Educated farmers also read and write and have the ability to read 'Za a Chikumbi', a local farmers' newsletter produced by the Department of Agricultural Extension Services. The farmers who are able to read are more likely to be exposed to information regarding the environmental benefits of agroforestry (Thangata, 2003).

Perceived usefulness and perceived ease of use were also significant. These results call for intensive and proper sensitization and training of farmers on the benefit of agroforestry, so that when they clearly understand the usefulness of agroforestry, they cannot see it as difficult to practice and not useful. The perception that farmers have towards a technology plays a major role in influencing their beliefs about practicing that technology, beliefs influence their attitude about practicing/ using that technology, attitude influence their intentions to practice/use a technology and their intention determines the level practice/usage/adoption of the technology (Yang, 2004; and Burton-Jones and Hubona, 2006; Wang and Qualls, 2007). Age of the household head was not significant but it had negative coefficient.

\section{Gaps in Implementation and Scaling up of Agroforestry Technologies During MAFE Project Implementation Period}

MAFE used sensitization meetings and community participatory appraisals to introduce the project to the communities. The project applied the principle of catchment conservation, where the whole community within the catchment area was involved in identifying the problems affecting their livelihoods and suggested possible solutions. In this process, EPA staff with help from district staff, chose the degraded catchments and sub-grouped the communities.

The MAFE project was imposed on farmers. They were just told that they will be involved in the project and that they will be given tree seeds and tree seedlings to plant in the fields, fields' boundary, homestead and woodlots. This shows that the farmers did not understand the project objectives well right from the beginning or that the sensitization was not very effective for farmers to conceptualize the project. It was 
Creative commons User License: CC BY-NC-ND

Abstracted by: EBSCOhost, Electronic Journals Service (EJS),

Google Scholar, Directory of Open Access Journals (DOAJ),

Journal Seek, Scientific Commons,

Food and Agricultural Organization (FAO), andCABI
Journal of Agricultural Extension

Vol. 20 (1) June, 2016

ISSN(e): 24086851; ISSN(Print); 1119944X

http://journal.aesonnigeria.org

http://www.ajol.info/index.php/iae

Email: editorinchief@aesonnigeria.org

found that this was so because sensitization meetings were done by government extension staff that had inadequate time, overloaded and preoccupied with other agricultural activities thereby not concentrating on MAFE project activities. Key informants recommended that for future projects the government should commit field staff on full time basis, unlike the setup of MAFE project where full time personnel were only at central level. It was also recommended that lead farmers should be elevated in order to fill the extension gap which may also affect future projects.

The study found that Farmers in the targeted sites were not fully sensitized because the project used top down approaches leading to the failure by most farmers to properly understand the objectives of the project. The study also found out that farmers were active during project implementation because they were given free tree seeds and seedling for their fields, woodlots and homesteads, which incentivized them. These were some of the reasons why most of the farmers did not continue with project activities after the project phased out in 2002. Similarly, the technologies did not scale up because of lack of incentives among non-targeted and other farmers after the project phase out.

The study also found out that the designing of the project was not flexible because it was not incorporating the changes during implementation based on lessons learnt. This means that future projects should use bottom up approaches, involve farmers during design and implementation, and be flexible to incorporate lessons learnt for effective project implementation and sustained outcomes. The project applied community based monitoring and evaluation approaches with farmers through field visits, review meetings and reporting. The project empowered EPA staff to conduct the trainings while the project provided materials for the trainings. The trainings that were offered included, nursery establishment, tree nursery management and transplanting, field tree management, biomass incorporation, group dynamics, community based monitoring, problem diagnosis, seed collection and different types of agroforestry technologies. The study found out that although all the planned trainings were done in time in the initial years of the project, the trainings were done off season or not done at all in the later years. Where they were done, it only depended on the performance and commitment of the agricultural extension staff in the EPAs. This negatively affected the implementation of the project.

The project had limited coordination with other relevant stakeholders during project planning and implementation. The Land Resources Conservation Department, which coordinated implementation of the project, only worked in partnership with the department of forestry despite the existence of other relevant stakeholders like the Department of Environment, the Department of Energy and Natural resources, Forest Research Institute of Malawi and World Agroforestry Centre. There was no phase out strategy for the project resulting in an abrupt winding up of the project. This was also one of the reasons why the farmers could not sustain project activities and why the project did not scale up after phase out and that access to extension services greatly reduced after the project phased out. 
Creative commons User License: CC BY-NC-ND

Abstracted by: EBSCOhost, Electronic Journals Service (EJS),

Google Scholar, Directory of Open Access Journals (DOAJ),

Journal Seek, Scientific Commons,

Food and Agricultural Organization (FAO), andCABI
Journal of Agricultural Extension

Vol. 20 (1) June, 2016

ISSN(e): 24086851; ISSN(Print); 1119944X

http://journal.aesonnigeria.org

http://www.ajol.info/index.php/jae

Email: editorinchief@aesonnigeria.org

\section{Current Situation}

In Malawi, currently there is no specific strategy to scale up agroforestry in the country despite the presence of many players on the ground. This emphasizes on the need to finalize the development of Agroforestry Strategy of Malawi by National Agroforestry Steering Committee (NASC) of Malawi whose draft was produced in January 2008. The implementation of National Agroforestry Strategy will involve various stakeholders depending on their strengths. The National Agroforestry Research and Development Forum (NARDF) will have the overall responsibility and will be the custodian of the strategy. Finalizing the strategy will promote implementation and scale up of the agroforestry technologies and also coordination among different partners involved in agroforestry.

Currently there is high vacancy rate and farmer-extension worker ratio is out of proportion due to combined efforts of natural attrition and HIV/AIDS pandemic (1 extension worker to 2551 farm-families against the recommended ratio of 1: 1000 Malawi Government, 2012). The Department of Land Resources Conservation in the Ministry of Agriculture and Water Development in Malawi should identify and build capacity of more lead farmers on agroforestry technologies.

\section{Best- bet Technologies for Scaling up Agroforestry}

Best-bet Agroforestry technology is a technology which is culturally practiced and promising. It has proved popular, easy to manage, beneficial to farmers and fits well in the traditional cultures, value and farming practices. The study found different general best - bet technologies depending on the purpose of the agroforestry tree species (Table 2). Specifically, farmers in Ntcheu, uses Tephrosia than other fertilizer agroforestry tree species due to its resistance to termites' attack and quick soil fertility restoration

\section{Table 2: Recommended best-bet technologies for scaling-up agroforestry}

\begin{tabular}{|c|c|c|}
\hline Agroforestry tree category & $\begin{array}{l}\text { Agroforestry } \\
\text { technology }\end{array}$ & Recommended Tree species \\
\hline Soil Fertility Improvement & Undersowing, DSI & $\begin{array}{l}\text { Tephrosia vogelii, Tephrosia Candida } \\
\text { and Acacia polyacantha }\end{array}$ \\
\hline Fuelwood/Poles & $\begin{array}{l}\text { Boundary, homesteads and } \\
\text { woodlot planting }\end{array}$ & $\begin{array}{l}\text { Senna spectabilis, Senna siamea, } \\
\text { Acacia galphinni and acacia }\end{array}$ \\
\hline \multicolumn{3}{|l|}{ polyacantha } \\
\hline Fodder & Woodlots and field boundary & Leucaena leucocephala \\
\hline Fruits & $\begin{array}{l}\text { Homestead, field boundary } \\
\text { and orchards }\end{array}$ & All kinds of fruit trees \\
\hline
\end{tabular}


Creative commons User License: CC BY-NC-ND

Abstracted by: EBSCOhost, Electronic Journals Service (EJS),

Google Scholar, Directory of Open Access Journals (DOAJ),

Journal Seek, Scientific Commons,

Food and Agricultural Organization (FAO), andCABI
Journal of Agricultural Extension

Vol. 20 (1) June, 2016

ISSN(e): 24086851; ISSN(Print); 1119944X

http://journal.aesonnigeria.org

http://www.ajol.info/index.php/jae

Email: editorinchief@aesonnigeria.org

\section{Conclusion and Recommendations}

The study concluded that scaling up of agroforestry technology can be achieved by providing quality and reliable agroforestry extension services and effective involvement of farmers and support of field staff in agroforestry projects is key for scaling up of the technologies.

The following recommendations were made

- Farmers and extension workers should be actively engaged in the design and implementation of agroforestry projects for scale up

- Agroforestry extension approaches like group mobilization, field days, follow up visits, demonstration plots and training should be promoted for farmers to perceive the usefulness of the technologies to enhance scale up.

- Future agroforestry projects should not provide free tree seeds and seedlings beyond initial year as they negatively affect project sustainability and scale up.

- Undersowing with Tephrosia vogelii should be promoted for quick soil fertility improvement and DSI with Faidhabia albida for its long term pattern

- The National Agroforestry Steering Committee of Malawi should finalize the development of agroforestry strategy and strengthen coordination and partnership among stakeholders involved in agroforestry.

- Homesteads and boundary planting should also be encouraged for soil fertility, food security, income, poles, and seed bank for technology scale up in tobacco growing districts. This so because farmers do not commonly plant agroforestry tress in tobacco fields.

- National tree planting season can be utilized to promote agroforestry tree planting,

\section{References}

Agresti, A. (2007). An Introduction to Categorical Data Analysis. $2^{\text {nd }}$ edition. New Jersey: John Wiley \& Sons, Inc, Publications.

Burton-Jones, A. and Hubona, G.S. (2006): The mediation of external variables in the technology acceptance model: $\mathrm{Pp}$ 706-71. Available online at:http://www.dl.acm.org/citation.cfm?id=1232268

Chamdimba, O.Y. (2003). Socio-Economic Factors affecting farmer adoption of Organic Soil Fertility Technologies in Lilongwe, Machinga and Blantyre ADDs: The Case of Tephrosia vogelli and Mucuna pruriens. MSc Thesis, University of Malawi. Bunda College of Agriculture. Lilongwe, Malawi pp 74-78

Field, A. (2000). Discovering Statistics. Using SPSS for Windows. London:- SAGE Publications.

Gujarati, D (2004). Basic Econometrics, Fourth Edition: New Delhi, The McGraw-Hill Companies, United Kingdom.

Jabbar, M.A., Beyene, H., Saleeem, M.A. and Gebreselassie, S. (1998). Adoption pathways for new agricultural Technologies: An approach and an application to vertisol management technology in Ethiopia. (Socioeconomic and Policy 
Creative commons User License: CC BY-NC-ND

Abstracted by: EBSCOhost, Electronic Journals Service (EJS),

Google Scholar, Directory of Open Access Journals (DOAJ),

Journal Seek, Scientific Commons,

Food and Agricultural Organization (FAO), andCABI
Journal of Agricultural Extension

Vol. 20 (1) June, 2016

ISSN(e): 24086851; ISSN(Print); 1119944X

http://journal.aesonnigeria.org

http://www.ajol.info/index.php/jae

Email: editorinchief@aesonnigeria.org

Research working Paper No. 23). Ethiopia: International Livestock Research Institute. Available online at: http//www.cgspace.cgiar.org/handle/10568/49769

Kamoto J.F., Clarkson G., Dorward P.T., Shepherd D.D (2013). Doing more harm than good? Community based natural resourcemanagement and the neglect of local institutions in policydevelopment. Land Use Policy 35 (2013) 293-301.

Kwesiga, E., Akinnifesi, F.K., Mafongoya, P.L., McDermott, M.H. and Agumya, A. (2003). Agroforestry research and development in Southern Africa during the 1990s: Review and challenges ahead. Agroforestry Systems. 59, 173-186. Available online at:

http//www.link.springer.com/article/10.1023/B:AGFO.0000005222.68054.38

Makumba, W.(2003). Nitrogen use efficiency and Carbon Sequestration in Legume Tree-Based agroforestry Systems: A Case Study of Malawi. Published PhD Thesis, University of Pretoria, South Africa. Available online at: http//.worldagroforestry.org/downloads/Publications/PDFS/ja06066.pdf

Malawi Government. (2000). National Land Resources Management Strategy. Lilongwe, Malawi.

Malawi Government. (2012). Guide to Agricultural Production and Natural Resources Management Handbook. Department of Agricultural Extension Services, Lilongwe, Malawi. Pp 290-292.

Matata P. Z. (2009) Dissemination pathways for scaling up agroforestry technologies in western Tanzania. Agricultural Research Institute, Tumbi, Tanzania

Ozor, N.,C.J. Garforth, and M.C. Madukwe (2013)Farmers' willingness to pay for agricultural extension service: Evidence from Nigeria. Journal of International Development Vol. 25 Issue 3: 382-392; DOI: 10.1002/jid.1849. Available online at: http://onlinelibrary.wiley.com/doi/10.1002/jid.1849/abstract

Policy Analysis and Sustainable Agricultural Development (PASAD. (2005). in Central, Eastern Europe and Southern Africa Final Report. Bonn, Germany, pp.4-12.

Thangata, P.H., Alavalapati, J.R.R. (2003). Agroforestry Adoption in Southern Malawi: The Case of Mixed Intercropping of Gliricidia Sepium and Maize. Agricultural Systems.2003. Vol. 78 issue 1:57-71.Available online at: http//www.scielo.org.co/pdf/bccm/v17n1/v17n1a03.pdf

Wang, Y. and Qualls, W. (2007): Towards a theoretical model of a technology adoption in hospitality organization: pp 560-573.

Yang, K.C.C. (2004): Exploring factors affecting the adoption of mobile commerce in Singapore, Singapore, pp 257-278.Available online at: http://www.researchgate.net/publication/222927288 Exploring factors affectin $\mathrm{g}$ the adoption of mobile commerce in Singapore 